\title{
Performance of family-owned firms: The impact of gender at the management level
}

\author{
Elisabete Gomes Santana Félix ${ }^{(1)}$ §, Daniela Sofia Taniça David ${ }^{(2)}$ \\ (1) Assistant Professor at the University of Évora and Researcher at CEFAGE-UÉ \\ University of Évora, Department of Management and CEFAGE-UÉ \\ Largo dos Colegiais, no 2, 7000-803 Évora, Portugal \\ Telephone number: +351266740892 \\ Fax number: +351266740807 \\ E-mail: efelix@uevora.pt \\ (2) Master in Management, specialization in Finance \\ University of Évora, Department of Management \\ E-mail:m11552@alunos.uevora.pt
}

\begin{abstract}
Purpose

The purpose of this article is to analyze the impact of gender (F/M), at the management level, on the family company's performance.

\section{Design/methodology/approach}

Company size, age, region and business sector were used as control variables in order to confirm the adjustment of our model to the theory. GMM dynamic panel models were used in order to control for: endogeneity; time-invariant characteristics; possible collinearity between independent variables; effects from possible omission of independent variables; elimination of non-observable individual effects; and the correct estimation of the relationship between the dependent variable in the previous and current periods. The study used data from 199 Portuguese family companies, from 2006 to 2014.

\section{Findings}

The results confirm the hypothesis from corporate governance literature which argues that board diversity is potentially positively related to firm performance, showing that the presence of a female element in family firms' direction has positive impacts on their performance, compared to those with only male elements. Also, the results show that region and sector of activity are factors influencing family firm performance. Finally, the study confirms that company size and age are variables helping to explain these companies' life-cycle.

\section{Originality/value}

The study contributes to the literature on family firms, regarding the effect of gender on family firm performance. The use of dynamic panel data models will make a strong contribution to this, as the problem of endogeneity is dealt with correctly here through using these models, and the possible collinearity between independent variables and correct estimation of the relationship between the dependent variable in previous and current periods.
\end{abstract}

Keywords: Age, Business Sector, Company size, Family Firm, Gender, Region, Performance.

Paper type Research paper

$\S$ Corresponding author 